\title{
Serum concentrations of antimicrobial peptide cathelicidin LL-37 in patients with bacterial lung infections
}

\author{
KAROL MAJEWSKI ${ }^{1,2}$, ELŻBIETA KOZŁOWSKA ${ }^{l}$, PAULINA ŻELECHOWSKA ${ }^{l}$, \\ EWA BRZEZIŃSKA-BEASZCZYK ${ }^{1}$
}

'Department of Experimental Immunology, Medical University of Lodz, Lodz, Poland

${ }^{2}$ Pulmonary Disease Hospital, Lodz, Poland

\begin{abstract}
Nowadays, data indicate that antimicrobial peptides play an important role in immunological defense. Human cathelicidin LL-37 possesses a broad spectrum of antimicrobial properties against Gram-positive and Gram-negative bacteria, and is thereby an important component of defense mechanisms within the respiratory tract. In this study, we determined the LL-37 serum level in patients with pneumonia caused by different bacteria species in comparison with healthy subjects. Twenty-two patients with pneumonia caused by coccal Gram-positive bacteria (I), 16 patients with pneumonia caused by Haemophilus influenzae (II), 29 patients with pneumonia caused by members of the Enterobacteriaceae (III), 13 patients caused by non-fermenting Gram-negative bacteria (IV), and 30 healthy controls were enrolled in the study. Serum LL-37 concentration was measured using an enzyme-linked immunosorbent assay (ELISA). The mean LL-37 concentration in pneumonia patients was significantly higher in group I $(p=0.0032)$, group II $(p=0.0022)$, and group III $(p=0.019)$, and significantly lower in group IV $(p=0.000004)$ as compared with healthy volunteers. Our data suggest that LL-37 plays an important role in defense mechanisms during pneumonia. The reduced level of this peptide in subjects with pneumonia caused by opportunistic bacteria may reflect weakened immune system reactivity in these patients.
\end{abstract}

Key words: pneumonia, immune system, antimicrobial peptides, cathelicidin LL-37, host defense.

(Centr Eur J Immunol 2018; 43 (4): 453-457)

\section{Introduction}

The main function of the immune system is to protect the host against different pathogens, such as bacteria, viruses, and fungi. In response to infection, first mechanisms of innate immunity are involved, in which different body cells such as neutrophils, macrophages, NK cells, dendritic cells, mast cells as well as various humoral factors, i.e. complement proteins, acute phase proteins, and cytokines, play roles. Acting together, these cells and humoral factors produce an inflammatory response to eliminate the invading microorganisms. Without a doubt, in antimicrobial defense, an extremely important role is played by the adaptive immunity mechanisms, in which B cells, different subsets of $\mathrm{T}$ lymphocytes, and antibodies are involved. Nowadays, more and more data indicate that in antimicrobial defense some small molecules, such as cathelicidins and defensins, take part. From among these antimicrobial peptides, cathelicidin LL-37, the only known member of the cathelicidin family expressed in humans, has essential importance [1].

Peptide LL-37 is produced by mucosal epithelial cells, neutrophils, monocytes, macrophages, mast cells, NK cells, T and B lymphocytes, adipocytes, and keratinocytes. Its expression is regulated by various endogenous factors, including proinflammatory cytokines, growth factors, as well as an active form of vitamin D. Cathelicidin LL-37 possesses a broad spectrum of antimicrobial properties against Gram-positive and Gram-negative bacteria with microbicidal activity against many different species and strains. It exhibits antiviral activity and acts against fungal infection, as well. Peptide LL-37 directly kills pathogens by disrupting their membranes and participates in the neutralization of biological activity of bacterial endotoxins. Furthermore, it can re-engineer bacterial biofilms and may prevent their formation. Additionally, LL-37 strongly affects inflammatory processes, as acts as a chemoattractant for neutrophils, monocytes, macrophages, eosinophils, and

Correspondence: Prof. Ewa Brzezińska-Błaszczyk, Department of Experimental Immunology, Medical University of Lodz,

251 Pomorska St., 92-213 Lodz, Poland, e-mail: ewab@csk.umed.lodz.pl

Submitted: 7.04.2017; Accepted: 12.06.2017 
mast cells [1-3], stimulates chemokine production, increases chemokine receptor expression, and induces interleukin (IL)-1b generation by monocytes. In concert with IL-1b, peptide LL-37 promotes the inflammatory response of macrophages and directs their differentiation toward macrophages with a proinflammatory signature [4]. Moreover, peptide LL-37 influences innate and adaptive immune responses developed in response to infection. It restrains programmed cell death by enhancing expression of the anti-apoptotic BcL-xl protein [5], and by blocking the activity of caspase- 3 activity [6]. This results in the suppression of neutrophil apoptosis, which extends the neutrophil lifespan and increases phagocytosis. LL-37 up-regulates the autophagy-related gene expression in macrophages and induces autophagosome formation to promote the killing of intracellular bacteria, as well [7]. Peptide LL-37 affects the Toll-like receptor (TLR)-mediated response and transports self-DNA into monocytes and plasmacytoid dendritic cells, leading to activation of TLR9 and production of type I interferons (IFNs) $[8,9]$. This peptide may modulate dendritic cell differentiation and dendritic cell-induced T-cell polarization [10] and can up-regulate CD86 and HLA-DR expression in dendritic cells [11]. LL-37 significantly increases migration of $\mathrm{CD}^{+} \mathrm{T}$ cells, as well [12].

Cathelicidin LL-37 is produced by airway epithelial cells and immune cells that are resident in or recruited to the respiratory tract. The presence of LL-37 in bronchoalveolar lavage (BAL) fluid, nasal lavage, tracheal aspirate samples obtained from new-born children, sputum, and saliva was documented. Thus, it is obvious that this peptide contributes to the barrier function of intact respiratory epithelia and it is an important component of defense mechanisms within the respiratory tract. Hence, it can be assumed that LL-37 might be involved in the immune response in the course of lung bacterial disease. The exact role of this peptide in defense mechanisms against bacteria within the respiratory tract is not well known and the data are not entirely clear. Therefore, in this study, we sought to determine the cathelicidin LL-37 serum level in patients with lung infection caused by different varieties of bacteria and to compare them with those of healthy subjects.

\section{Material and methods}

\section{Study participants}

Eighty adult patients with pneumonia symptoms and 25 healthy adult volunteers were included in this study. Subjects were selected from the patients of the Pulmonary Disease Hospital in Lodz. All individuals were subjected to an initial evaluation that included: a clinical examination, radiological findings, basic laboratory blood parameters including alanine aminotransferase (ALAT), aspartate aminotransferase (AspAT), total bilirubin, urea, creatinine, glucose, C-reactive protein (CRP), white blood cell (WBC) count, and microbiology standard laboratory methods. Exclusion criteria were as follows: taking antibiotics for last three months, taking immunosuppressive or antihistamine agents, chronic inflammatory diseases, systemic diseases, immunological disorders (AIDS, allergy), and neoplastic processes. Patients were divided into four clinical groups, according to their lung infectious agent. The groups were the following: subjects with pulmonary infection caused by coccal Gram-positive bacteria, i.e. Staphylococcus aureus $(n=17)$, Streptococcus pneumoniae $(n=4)$, or Streptococcus pyogenes $(n=1)$ (group I); subjects with pneumonia caused by Haemophilus influenzae ( $n=16$; group II); subjects with pneumonia caused by members of the Enterobacteriaceae, i.e. Escherichia coli $(n=12)$, Enterobacter cloacae $(n=5)$, Klebsiella pneumoniae $(n=3), K$. mobilis $(n=1)$, K. oxytoca $(n=3)$, Serratia liquefaciens $(n=1)$, Raoultella terrigena $(n=1)$, Raoultella ornithinolytica $(n=1)$, E. aerogenes $(n=1)$, Proteus mirabilis $(n=1)$ (group III); and subjects with pneumonia caused by non-fermenting Gram-negative bacteria, i.e. Pseudomonas aeruginosa $(n=10)$, Stenotrophomonas maltophilia $(n=2)$, Acinetobacter baumannii $(n=1)$ (group IV). Twenty-five healthy subjects were randomly selected from a control group (group V). All subjects were informed about the aims and methods of the study and expressed their written informed consent for participation in the study. The study protocol was approved by the Bioethics Committee of the Medical University of Lodz (approval no. RNN/785/13/KB).

\section{Laboratory measurements}

Blood samples were obtained from all the patients before the commencement of the treatment and from the control subjects. Blood samples were collected between 8 am and 9 am after ensuring at least 8 h overnight fasting. WBC count was determined using a Sysmex XS-1000i TM automated hematology analyzer (Sysmex Corporation, Japan) in blood samples collected into tubes with an anticoagulant. For LL-37 and CRP measurement blood samples were collected directly into serum separator tubes and centrifuged (10 min, $3500 \mathrm{rpm}$ ). Immediately, after the centrifugation process, CRP serum levels were determined using a latex-enhanced immunoturbidimetry and automatic analyzer, Dirui CS-400 (Dirui, China). For LL-37 measurement, all serum samples were kept frozen at $-80^{\circ} \mathrm{C}$ until analysis. The concentration of LL-37 in serum was assessed using an ELISA kit (MyBioSource, USA).

\section{Statistical analysis}

The statistical analysis was performed using Statistica 12.5 (StatSoft Inc., USA). Simple descriptive statistics (means, standard deviation (SD)) were generated for LL-37, WBC and CRP variables. Normality of distribution was tested with the Shapiro-Wilk test. Serum concentration 
Table 1. Demographic and clinical characteristics of the study population

\begin{tabular}{lccccc}
\hline & Group I & Group II & Group III & Group IV & Control group \\
\hline$n$ & 22 & 16 & 29 & 13 & 25 \\
\hline Age (years) & $65 \pm 15$ & $70 \pm 14$ & $70 \pm 8$ & $74 \pm 9$ & $44 \pm 13$ \\
\hline Gender (M/F) & $16 / 6$ & $13 / 3$ & $15 / 14$ & $10 / 3$ & $12 / 13$ \\
\hline ALAT (U/l) & $23.68 \pm 14.73$ & $15.87 \pm 5.79$ & $24.17 \pm 12.96$ & $17.33 \pm 8.64$ & $24.44 \pm 12.57$ \\
\hline AspAT (U/l) & $21.86 \pm 10.39$ & $21.13 \pm 8.42$ & $24.59 \pm 15.36$ & $16.58 \pm 5.04$ & $22.48 \pm 5.71$ \\
\hline Total bilirubin $(\mathrm{mg} / \mathrm{dl})$ & $0.39 \pm 0.18$ & $0.45 \pm 0.13$ & $0.46 \pm 0.28$ & $1.06 \pm 1.95$ & $0.56 \pm 0.22$ \\
\hline Urea (mg/dl) & $37.34 \pm 11.91$ & $35.29 \pm 17.47$ & $32.32 \pm 17.08$ & $41.43 \pm 9.20$ & $25.66 \pm 5.68$ \\
\hline Creatinine (mg/dl) & $0.93 \pm 0.24$ & $0.86 \pm 0.17$ & $0.85 \pm 0.23$ & $1.37 \pm 1.44$ & $0.81 \pm 0.15$ \\
\hline Glucose (mg/dl) & $102.64 \pm 17.87$ & $98.67 \pm 12.05$ & $101.39 \pm 15.30$ & $102.54 \pm 16.08$ & $79.16 \pm 14.16$ \\
\hline $\begin{array}{l}\text { Values expressed as mean } \pm \text { SD, } M-\text { male, F- female, AspAT - aspartate transaminase, ALAT - alanine transaminase, WBC - white blood cell count, } \\
\text { CRP - C-reactive protein }\end{array}$ & & &
\end{tabular}

of LL-37 and CRP, as well as WBC count, were compared using the Mann-Whitney U test. The relationships between the serum concentrations of LL-37 and CRP in all groups were expressed as Spearman's correlation coefficients. $p<0.05$ was considered statistically significant.

\section{Results}

Baseline characteristics of the study subjects are shown in Table 1. In group I, the mean $( \pm \mathrm{SD})$ age was $65 \pm 15$ years, and the male/female ratio was $16 / 6$. In group II the mean age $\pm \mathrm{SD}$ was $70 \pm 14$ years, and the male/female ratio was 13/3, and in the Enterobacteriaceae group (III) the mean age \pm SD was $70 \pm 8$ years, and the ratio was $15 / 14$. In group IV, the mean age \pm SD was $74 \pm 9$ and there were 10 men and 3 women. In the control group the mean age \pm SD was $44 \pm 13$ years and the proportion of men and women was as 12 to 13 . Age and gender distributions were not statistically different between the groups. The levels of basic laboratory parameters, including AspAT, ALAT, total bilirubin, urea, creatinine, and glucose, in all groups were within normal ranges.

The serum levels of LL-37 in patients infected with Gram-positive bacteria (group I), patients with pneumonia caused by $H$. influenzae (group II), patients with infection caused by Enterobacteriaceae family pathogens (group III), and patients infected with Gram-negative nonfermenting rods (group IV) ranged from 0.11 to $90.59 \mathrm{ng} / \mathrm{ml}$, from 0.09 to $33.27 \mathrm{ng} / \mathrm{ml}$, from 0.11 to $86.12 \mathrm{ng} / \mathrm{ml}$, and from 0.10 to $0.77 \mathrm{ng} / \mathrm{ml}$, respectively. In healthy subjects, LL-37 concentration in serum ranged from 0.25 to 12.79 $\mathrm{ng} / \mathrm{ml}$. The mean concentrations of serum LL-37 in groups I, II, III, and IV were $5.25 \pm 19.25 \mathrm{ng} / \mathrm{ml}, 3.79 \pm 8.89$ $\mathrm{ng} / \mathrm{ml}, 8.92 \pm 19.65 \mathrm{ng} / \mathrm{ml}$, and $0.29 \pm 0.20 \mathrm{ng} / \mathrm{ml}$, respectively. The mean concentration of LL-37 in healthy individuals was $2.71 \pm 3.57 \mathrm{ng} / \mathrm{ml}$ (Table 2). Statistical analysis revealed statistical differences in group I $(p=0.0032)$,
Table 2. LL-37, WBC, and CRP values of the pneumonia patients and control subjects

\begin{tabular}{lccc}
\hline & LL-37 $(\mathbf{n g} / \mathbf{m l})$ & WBC $(\times \mathbf{1 0}$ /l) & CRP $(\mathbf{m g} / \mathbf{l})$ \\
\hline Group I & $5.25 \pm 19.25$ & $9.12 \pm 2.70$ & $70.14 \pm 81.57$ \\
\hline Group II & $3.79 \pm 8.89$ & $9.36 \pm 4.31$ & $59.10 \pm 79.10$ \\
\hline Group III & $8.92 \pm 19.65$ & $8.99 \pm 3.36$ & $46.60 \pm 79.71$ \\
\hline Group IV & $0.29 \pm 0.20$ & $12.53 \pm 9.87$ & $50.30 \pm 37.27$ \\
\hline Control group & $2.71 \pm 3.57$ & $5.72 \pm 1.29$ & $1.38 \pm 1.23$ \\
\hline $\begin{array}{l}\text { Values expressed as mean } \pm S D ; \text { WBC }- \text { white blood cell count; } \\
\text { CRP }- \text { C-reactive protein }\end{array}$
\end{tabular}

group II $(p=0.0022)$, group III $(p=0.019)$, and group IV $(p=0.000004)$ as compared with healthy volunteers. What is more, there were no significant differences in LL-37 concentration between groups I, II, III and IV.

There were significant differences for WBC between study groups and healthy controls (I vs. V $-p=0.000001$; II vs. V $-p=0.0016$; III vs. V $-p=0.000008$; IV vs. $\mathrm{V}-p=0.0032$ ). Similarly, there were significant differences for CRP concentration between study groups and healthy controls (I vs. V $-p=0.000000$; II vs. $\mathrm{V}-p=0.000000$; III vs. $\mathrm{V}-p=0.000000$; IV vs. $\mathrm{V}-p=0.0000000$ ) (Table 2). Significantly higher levels of CRP and WBC in the patients from groups I, II, III, and IV, compared to the control group, confirmed the ongoing infection. Spearman's correlation tests revealed no statistically significant correlations between LL-37 and CRP serum levels and LL-37 serum levels and WBC count $(p>0.05)$.

\section{Discussion}

Data relating to cathelicidin LL-37 expression in the course of bacterial infections are scarce. It was shown 
that neonates with congenital pneumonia had significantly higher serum concentrations of LL-37 [13], and newborn infants with pulmonary infections exhibited elevated LL-37 levels in tracheal aspirates [14], as compared with healthy controls. It was documented that circulating levels of LL-37 in children with post-infectious bronchiolitis obliterans were higher than in healthy subjects [15]. Moreover, elevated circulating LL-37 levels in adult patients with pulmonary tuberculosis, in comparison with healthy subjects, were noted [16]. In our previous studies, we also observed significantly higher concentrations of this peptide in the serum of adult patients with pulmonary tuberculosis [17]. Significantly elevated LL-37 levels in bronchoalveolar lavage (BAL) fluid of children with pulmonary tuberculosis were noted, as well [18]. Visser et al. [19] documented higher levels of this peptide both in serum and cerebrospinal fluid of children with tuberculous meningitis compared with those of patients with bacterial and viral meningitis. Elevated LL-37 levels in gingival crevicular fluid (GCF) [20] and in saliva [21] of patients suffering from periodontitis were also reported. It should be emphasized that a significant elevation of LL-37 gene expression in blood of patients with active pulmonary tuberculosis, compared with those in subjects with latent tuberculosis and healthy individuals, was observed [22]. Additionally, it was stated that expression level of cathelicidin mRNA in the skin of patients with infective cellulitis was elevated, as compared with the expression in the skin of healthy volunteers [23]. On the other hand, in diabetic foot ulcer biopsies, the LL-37 expression level was low or zero in comparison with healthy skin, and cultured epidermal cells from these biopsies infected with $S$. aureus showed lower LL-37 expression compared with cell cultures from healthy donors' skin [24]. It was also observed that Neisseria gonorrhoeae infection caused downregulation of LL-37 transcript and peptide levels in the cervical epithelial cell line [25]. Decreased circulating LL-37 levels in patients with leprosy [26] and in the course of septic shock $[27,28]$ were documented, as well.

In this study we evaluated the serum levels of peptide LL-37 in patients with pneumonia caused by different bacterial pathogens, i.e. some Gram-positive bacterial species (S. aureus, S. pneumoniae, S. pyogenes), H. influenzae, various species of the Enterobacteriaceae family (E. coli, E. cloacae, K. pneumoniae, K. mobilis, K. oxytoca, S. liquefaciens, $R$. terrigena, $R$. ornithinolytica, E. aerogenes, $P$. mirabilis), and some species of opportunistic bacteria (P. aeruginosa, S. maltophilia, A. baumannii). For comparison, we checked LL-37 concentrations in serum of healthy individuals. We demonstrated that serum concentrations of LL-37 in subjects with pneumonia caused by different bacterial species were significantly higher than in healthy controls. It should be noted that there were no statistically significant differences in LL-37 level in patients with pneumonia caused by the different etiological agent. More- over, we have observed that in patients with opportunistic bacterial infection the circulating level of this cathelicidin was significantly lower than in healthy subjects.

The respiratory tract is especially exposed to contact with different pathogens entering via inhalation and through nasal and oral mucosal surfaces. Thus, the innate and adaptive immune responses within the respiratory system are very important. Growing evidence indicates that antimicrobial peptides, including cathelicidin LL-37, take part in the pathomechanism of various respiratory diseases [29-31], i.e. cystic fibrosis [32], interstitial lung disease [33], and bronchiolitis [34, 35]. Furthermore, as LL-37 has a broad spectrum of antimicrobial activities $[36,37]$ and can directly kill various Gram-positive and Gram-negative bacteria [38-40], one can assume that it plays an important role in defense mechanisms during lung infectious diseases. Our observation that in the course of bacterial pneumonia caused by various pathogenic bacteria strains the LL-37 level is raised seems to confirm such a suggestion. The reduced level of this peptide in subjects with pneumonia caused by opportunistic bacteria may reflect weakened immune system reactivity in these patients. However, further studies are needed to clearly explain the role of cathelicidin LL-37 in defense mechanisms in the course of infectious diseases within the respiratory system.

\section{Acknowledgments}

This study was supported by the Medical University of Lodz (grant no. 502-03/6-164-01/502-64-083).

The authors declare no conflict of interest.

\section{References}

1. Tjabringa GS, Ninaber DK, Drijfhout JW, et al. (2006): Human cathelicidin LL-37 is a chemoattractant for eosinophils and neutrophils that acts via formyl-peptide receptors. Int Arch Allergy Immunol 140: 103-112.

2. De Yang, Chen Q, Schmidt AP, et al. (2000): LL-37, the neutrophil granule- and epithelial cell-derived cathelicidin, utilizes formyl peptide receptor-like 1 (FPRL1) as a receptor to chemoattract human peripheral blood neutrophils, monocytes, and T cells. J Exp Med 192: 1069-1074.

3. Bąbolewska E, Brzezińska-Błaszczyk E (2015): Human-derived cathelicidin LL-37 directly activates mast cells to proinflammatory mediator synthesis and migratory response. Cell Immunol 293: 67-73.

4. van der Does AM, Beekhuizen H, Ravensbergen B, et al. (2010): LL-37 directs macrophage differentiation toward macrophages with a proinflammatory signature. J Immunol 185: 1442-1449.

5. Barlow PG, Li Y, Wilkinson TS, et al. (2006): The human cationic host defense peptide LL-37 mediates contrasting effects on apoptotic pathways in different primary cells of the innate immune system. J Leukoc Biol 80: 509-520. 
6. Nagaoka I, Tamura H, Hirata M (2006): An antimicrobial cathelicidin peptide, human CAP18/LL-37, suppresses neutrophil apoptosis via the activation of formyl-peptide receptor-like 1 and P2X7. J Immunol 176: 3044-3052.

7. Yuk JM, Shin DM, Lee HM, et al. (2009): Vitamin D3 induces autophagy in human monocytes/macrophages via cathelicidin. Cell Host Microbe 6: 231-243.

8. Chamilos G, Gregorio J, Meller S, et al. (2012): Cytosolic sensing of extracellular self-DNA transported into monocytes by the antimicrobial peptide LL37. Blood 120: 3699-3707.

9. Gregorio J, Meller S, Conrad C, et al. (2010): Plasmacytoid dendritic cells sense skin injury and promote wound healing through type I interferons. J Exp Med 207: 2921-2930.

10. Davidson DJ, Currie AJ, Reid GS (2004): The cationic antimicrobial peptide LL-37 modulates dendritic cell differentiation and dendritic cell-induced T cell polarization. J Immunol 172: 1146-1156.

11. Bandholtz L, Ekman GJ, Vilhelmsson M, et al. (2006): Antimicrobial peptide LL-37 internalized by immature human dendritic cells alters their phenotype. Scand J Immunol 63: 410-419.

12. Agerberth B, Charo J, Werr J, et al. (2000): The human antimicrobial and chemotactic peptides LL-37 and $\alpha$-defensins are expressed by specific lymphocyte and monocyte populations. Blood 96: 3086-3093.

13. Gad GI, Abushady NM, Fathi MS, Elsaadany W (2015): Diagnostic value of anti-microbial peptide, cathelicidin in congenital pneumonia. J Matern Fetal Neonatal Med 28: 2197-2200.

14. Schaller-Bals S, Schulze A, Bals R (2002): Increased levels of antimicrobial peptides in tracheal aspirates of newborn infants during infection. Am J Respir Crit Care Med 165: 992-995.

15. Li YN, Liu L, Qiao HM, et al. (2014): Post-infectious bronchiolitis obliterans in children: a review of 42 cases. BMC Pediatr 14: 238.

16. Zhan Y, Jiang L (2015): Status of vitamin D, antimicrobial peptide cathelicidin and $\mathrm{T}$ helper-associated cytokines in patients with diabetes mellitus and pulmonary tuberculosis. Exp Ther Med 9: 11-16.

17. Majewski K, Żelechowska P, Brzezińska-Błaszczyk E (2017): Circulating cathelicidin LL-37 in adult patients with pulmonary infectious diseases. Clin Invest Med 40: E1-E6.

18. Cakir E, Torun E, Gedik AH, et al. (2014): Cathelicidin and human $\beta$-defensin 2 in bronchoalveolar lavage fluid of children with pulmonary tuberculosis. Int J Tuberc Lung Dis 18: 671-675.

19. Visser DH, Solomons RS, Ronacher K (2015): Host immune response to tuberculous meningitis. Clin Infect Dis 60: 177187.

20. Türkoğlu O, Emingil G, Kütükçüler N, Atilla G (2009): Gingival crevicular fluid levels of cathelicidin LL-37 and interleukin-18 in patients with chronic periodontitis. J Periodontol 80: 969-976.

21. Davidopoulou S, Diza E, Sakellari D, et al. (2013): Salivary concentration of free LL-37 in edentulism, chronic periodontitis and healthy periodontium. Arch Oral Biol 58: 930-934.

22. Gonzalez-Curiel I, Castańeda-Delgado J, Lopez-Lopez N, et al. (2011): Differential expression of antimicrobial peptides in active and latent tuberculosis and its relationship with diabetes mellitus. Hum Immunol 72: 656-662.

23. Stryjewski ME, Hall RP, Chu VH, et al. (2007): Expression of antimicrobial peptides in the normal and involved skin of patients with infective cellulitis. J Infect Dis 196: 1425-1430.
24. Rivas-Santiago B, Trujillo V, Montoya A, et al. (2012): Expression of antimicrobial peptides in diabetic foot ulcer. J Dermatol Sci 65: 19-26.

25. Bergman P, Johansson L, Asp V, et al. (2005): Neisseria gonorrhoeae downregulates expression of the human antimicrobial peptide LL-37. Cell Microbiol 7: 1009-1017.

26. Matzner M, Al Samie AR, Winkler HM, et al. (2011): Low serum levels of cathelicidin LL-37 in leprosy. Acta Trop 117: 56-59.

27. Jeng L, Yamshchikov AV, Judd SE (2009): Alterations in vitamin $\mathrm{D}$ status and anti-microbial peptide levels in patients in the intensive care unit with sepsis. J Transl Med 7: 28.

28. Barbeiro DF, Barbeiro HV, Zampieri FG, et al. (2013): Cathelicidin LL-37 bloodstream surveillance is down regulated during septic shock. Microbes Infect 15: 342-346.

29. Doss M, White M, Tecle T, Hartshorn KL (2010): Human defensins and LL-37 in mucosal immunity. J Leukoc Biol 87: 79-92.

30. Tecle T, Tripathi S, Hartshorn KL (2010): Defensins and cathelicidins in lung immunity. Innate Immun 16: 151-159.

31. Tjabrinka G, Rabe KF, Hiemstra PS (2005): The human cathelicidin LL-37: a multifunctional peptide involved in infection and inflammation in the lung. Pulm Pharmacol Ther 18: 321-327.

32. Chen CI, Schaller-Bals S, Paul KP, et al. (2004): $\beta$-defensins and LL-37 in bronchoalveolar lavage fluid of patients with cystic fibrosis. J Cyst Fibros 3: 45-50.

33. Hizal M, Bruni C, Romano E, et al. (2015): Decrease of LL37 in systemic sclerosis: a new marker for interstitial lung disease? Clin Rheumatol 34: 795-798.

34. Gedik AH, Cakir E, Gokdemir Y, et al. (2015): Cathelicidin (LL-37) and human 32 -defensin levels of children with post-infectious bronchiolitis obliterans. Clin Respir J 11: 243 247.

35. Anderson RL, Hiemstra PS, Ward C, et al. (2008): Antimicrobial peptides in lung transplant recipients with bronchiolitis obliterans syndrome. Eur Respir J 32: 670-677.

36. Vandamme D, Landuyt B, Luyten W, Schoofs L (2012): A comprehensive summary of LL-37, the factotum human cathelicidin peptide. Cell Immunol 280: 22-35.

37. Kahlenberg JM, Kaplan MJ (2013): Little peptide, big effects: the role of LL-37 in inflammation and autoimmune diseases. J Immunol 191: 4895-4901.

38. Gad GI, Abushady NM, Fathi MS, Elsaadany W (2015): Diagnostic value of anti-microbial peptide, cathelicidin in congenital pneumonia. J Matern Fetal Neonatal Med 28: $2197-$ 2200.

39. Liu W, Dong SL, Xu F (2013): Effect of intracellular expression of antimicrobial peptide LL-37 on growth of Escherichia coli strain TOP10 under aerobic and anaerobic conditions. Antimicrob Agents Chemother 57: 4707-4716.

40. Vandamme D, Landuyt B, Luyten W, Schoofs L (2012): A comprehensive summary of LL-37, the factotum human cathelicidin peptide. Cell Immunol 280: 22-35. 